\title{
EFISIENSI SEBAGAI STRATEGI UNTUK MENINGKATKAN KINERJA KEUANGAN (STUDI KASUS: BMT UGT SIDOGIRI CABANG LUMAJANG)'
}

\author{
Qonitah Bakhitah \\ Departemen Ekonomi Syariah- Fakultas Ekonomi dan Bisnis-Universitas Airlangga \\ Email: qonitah.bakhitah-2015@feb.unair.ac.id
}

\author{
Muhammad Nafik H. R. \\ Departemen Ekonomi Syariah- Fakultas Ekonomi dan Bisnis-Universitas Airlangga \\ Email: muhammadnafik@feb.unair.ac.id
}

\begin{abstract}
:
This research aims to determine the efficiency as one of the strategies in increasing the Financial Performance of Baitul mal wattamwil UGT Sidogiri Lumajang. The method used in this research is a qualitative approach with a case study strategy. The object of this research is Baitul maal wattamwil UGT Sidogiri Lumajang. Data collection is done by interviewing informants from Baitul mal wattamwil UGT Sidogiri Lumajang. The results were conducted from observation and interviews by researchers to 3 informants, showed that the strategies by Baitul mal wattamwil included: controlling operational costs, increase thirdparty Funds (DPK) savings and time deposits, finance clearly directional, and improve our services and product features fee based income, innovating on the technologies used, targeting every employee, , providing training regarding skills needed by employees, performance appraisal systems, employee rewards and promotions based on their contribution in efforts to improve quality, sustainable productivity.

Keywords: Strategic, Efficiency, Finance performance, Baitul mal wattamwil UGT Sidogiri Lumajang
\end{abstract}

\section{PENDAHULUAN}

Keberadaan lembaga jasa kevangan mikro syariah seperti Baitul Maal wat Tamwil (BMT) yang bersifat koperasi syariah diharapkan bisa memajukan sektor usaha mikro di masyarakat sehingga mampu meningkatkan pertumbuhan ekonomi nasional. Kehadiran BMT di masyarakat dianggap sebagai jembatan untuk menghidupkan usaha-usaha skala kecil dengan pembiayaan tidak terlalu besar. Mengingat Indonesia masih merupakan negara berkembang yang butuh modal sangat besar untuk menggerakkan perekonomian menjadi lebih produktif di sektor riil, kehadiran BMT diharapkan lebih produktif menyalurkan pembiayaan dan pembinaan kepada masyarakat yang sulit mengakses pinjaman dari lembaga jasa kevangan besar seperti perbankan konvensional maupun syariah.

Pertumbuhan BMT di tanah air ini terus melesat, sebagaimana LKMS lainnya, tujuan utama lembaga ini adalah menyediakan permodalan bagi masyarakat yang melakukan usaha mikro dan kecil yang jumlahnya sangat banyak tetapi kesulitan mendapatkan akses permodalan dari lembaga keuangan formal seperti Bank. Selain itu, BMT mempunyai dua fungsi sekaligus yang

\footnotetext{
${ }^{1}$ Jurnal ini merupakan bagian dari skripsi Qonitah Bakhitah, NIM: 041511433149, yang diuji pada tanggal 25 Juni 2019.
} 
Bakhitah, et al/Jurnal Ekonomi Syariah Teori dan Terapan Vol. 6 No. 6 Juni 2019: 1287-1303; EFISIENSI SEBAGAI STRATEGI UNTUK MENINGKATKAN KINERJA KEUANGAN (STUDI KASUS: BMT UGT SIDOGIRI CABANG LUMAJANG)

pertama yaitu sebagai pengembangan harta (baitul tamwil) dan fungsi yang kedua yaitu menerima titipan dana zakat, infak, dan sedekah (baitul maal) serta mengoptimalkan distribusinya sesuai peraturan dan amanahnya.

Kinerja Kevangan merupakan hal yang perlu diperhatikan bagi setiap usaha yang dijalankan, tidak terkecuali dengan BMT, meskipun prinsip utamanya adalah beroperasi secara syariah dengan berbagai nilai idealitas atau nilai normatif, orientasi terhadap laba juga menjadi prioritas agar kesinambungan usahanya dapat dipertahankan. Ketidakstabilan kinerja keuangan BMT suatu ketika akan menjadi sebuah permasalahan karena hal ini akan menandakan kesiapan BMT untuk menghadapi pesaing atau bahkan tantangan yang sangat besar. BMT tidak dapat lagi mengandalkan modal kepercayaannya pada sentimen masyarakat tentang isu-isu syariah, seperti keharaman riba dan sistem bunga menjalankan sistem ekonomi berdasarkan syariat islam (Sadrah dkk, 2004). Apalagi Bank Syariah dan BPRS-BPRS dengan fasilitas dan permodalanya yang kuat semakin mempersempit ruang gerak BMTBMT. Oleh karena itu mau tidak mau BMT harus meningkatkan efisiensi usahanya agar mampu bersaing dan bertahan hidup.

Laba atau keuntungan suatu lembaga keuangan juga tergantung dari pendapatan yang diperoleh dan biaya operasional yang dikeluarkan untuk menjalankan aktivitasnya, untuk mencapai laba yang maksimum maka lembaga keuangan dapat meminimalkan biaya yang dikelvarkan. Sehingga lembaga keuangan harus tetap menjaga efisiensi biaya operasionalnya. Biaya operasional yang rendah akan meningkatkan peluang lembaga keuangan memperoleh laba. Oleh sebab itu, tingginya efisiensi operasional yang dimiliki suatu lembaga keuangan maka akan semakin tinggi pula kemampuan dalam meningkatkan laba. Dengan kata lain semakin efisien kinerja operasional lembaga keuangan, maka laba yang diperoleh semakin tinggi, sehingga kinerja keuangan lembaga keuangan juga semakin meningkat.

Untuk meningkatkan kinerja kevangan dan mampu bertahan di pasar, memerlukan strategi yang tepat bersama aspek pendukungnya, seperti sumber daya manusia, infrastruktur, budaya, dan inovasi yang terus-menerus. Perusahaan berusaha dengan berbagai cara untuk tetap berada di depan para pesaingnya dengan berbagai strategi yang dilakukan salah satunya yaitu berupaya agar tetap menjaga efisiensi dalam kegiatan operasionalnya seperti memanfaatkan infrastruktur yang ada, membutuhkan keterampilan baru, meluncurkan produk efisien untuk menghemat biaya, atau dengan menciptakan produk yang tergolong mudah tetapi dapat diterima dengan baik oleh masyarakat. 
Bakhitah, et al/Jurnal Ekonomi Syariah Teori dan Terapan Vol. 6 No. 6 Juni 2019: 1287-1303; EFISIENSI SEBAGAI STRATEGI UNTUK MENINGKATKAN KINERJA KEUANGAN (STUDI KASUS: BMT UGT SIDOGIRI CABANG LUMAJANG)

Koperasi BMT Usaha Gabungan Terpadu Sidogiri disingkat "Koperasi BMT UGT Sidogiri" yang mulai beroperasi pada tanggal 5 Rabiul Awal $1421 \mathrm{H}$ atau 6 Juni 2000 M. di Surabaya dan kemudian mendapatkan badan Hukum Koperasi dari Kanwil Dinas Koperasi PK dan M Propinsi Jawa Timur dengan SK Nomor: 09/BH/KWK.13/VII/2000 tertanggal 22 Juli 2000. BMT UGT Sidogiri didirikan oleh beberapa orang yang berada dalam satu kegiatan Urusan Guru Tugas Pondok Pesantren Sidogiri (Urusan GT PPS) yang di dalamnya terdapat orang-orang yang berprofesi sebagai guru dan pimpinan madrasah, alumni Pondok Pesantren Sidogiri Pasuruan dan para simpatisan yang menyebar di wilayah Jawa Timur. Koperasi BMT UGT Sidogiri membuka beberapa unit pelayanan anggota di kabupaten/kota yang dinilai potensial, salah satunya di Kabupaten Lumajang. Pada saat ini BMT UGT Sidogiri telah berusia 18 tahun dan sudah memiliki 277 Unit Layanan Baitul Maal wat Tamwil/Jasa Kevangan Syariah. Dalam perkembangannya BMT UGT Sidogiri memiliki aset Rp 2,2 triliun, volume usaha Rp 2,04 triliun dan anggota sebanyak 16.010. Koperasi BMT UGT Sidogiri berada di ranking 1 berdasarkan buku 100 Koperasi Besar Indonesia 2017 yang diterbitkan majalah Peluang Jakarta. Pada tahun 2017 Koperasi BMT UGT Sidogiri berhasil menempati ranking 1 Koperasi Besar Jawa Timur. Untuk tingkat nasional Koperasi BMT UGT Sidogiri berada pada ranking 4.

Berdasarkan uraian diatas, tujuan penelitian ini adalah untuk mengetahui efesiensi sebagai salah satu strategi meningkatkan kinerja keuangan yang dilakukan oleh suatu BMT berdasarkan konsep syariah karena didalam meningkatkan kinerja keuangan diperlukan sebuah upaya yang sesuai dengan kaidah-kaidah Syariah sehingga dapat berdampak terhadap kinerja keuangan BMT tersebut.

II. LANDASAN TEORI

Baitul Maal wat Tamwil (BMT) atau Balai Usaha Mandiri Terpadu adalah lembaga keuangan mikro yang dioperasikan dengan prinsip bagi hasil menumbuh kembangkan bisnis usaha mikro dalam rangka mengangkat derajat dan martabat serta membela kepentingan kaum fakir miskin, ditumbuhkan atas prakarsa dan modal awal dari tokoh-tokoh masyarakat setempat dengan berlandaskan pada sistem ekonomi yang salaam: keselamatan (berintikan keadilan), kedamaian, dan kesejahteraan. Sesuai dengan namanya, BMT terdiri atas dua fungsi utama, yaitu (Aziz, 2004):

1. Baitul Mal (rumah harta) lebih mengarah pada usaha-usaha pengumpulan dan penyaluran dana yang non-profit, seperti menerima titipan dana zakat, infak, dan sedekah serta mengoptimalkan distribusinya sesuai dengan peraturan dan amanahnya. 
Bakhitah, et al/Jurnal Ekonomi Syariah Teori dan Terapan Vol. 6 No. 6 Juni 2019: 1287-1303; EFISIENSI SEBAGAI STRATEGI UNTUK MENINGKATKAN KINERJA KEUANGAN (STUDI KASUS: BMT UGT SIDOGIRI CABANG LUMAJANG)

2. Baitul Tamwil (rumah pengembangan harta), melakukan pengembangan usaha-usaha produktif dan investasi dalam meningkatkan kualitas ekonomi pengusaha mikro dan kecil dengan cara mendorong kegiatan menabung dan menunjang pembiayaan kegiatan ekonomi. Usaha-usaha tersebut menjadi bagian yang tidak terpisahkan dari BMT sebagai lembaga pendukung kegiatan ekonomi masyarakat kecil dengan berlandaskan syariah.

Secara harfiah, baitul mal berarti rumah dana dan baitul tamwil berarti rumah usaha. Adapun baitul tamwil merupakan lembaga bisnis bermotif laba. Dari pengertian tersebut dapat ditarik suatu pengertian yang menyeluruh bahwa BMT merupakan organisasi bisnis yang juga berperan sosial. Secara umum peran BMT adalah melakukan pembinaan dan pendanaan yangberdasarkan sistem syariah. Peran ini menegaskan arti penting prinsip-prinsip syariah dalam kehidupan ekonomi masyarakat. Sebagai lembaga keuangan syariah yang bersentuhan langsung dengan kehidupan masyarakat kecil yangserba cukup dalam hal ilmu pengetahuan dan materi, maka BMT mempunyai tugas penting dalam mengemban misi keislaman dalam segala aspek kehidupan masyarakat.

\section{Efisiensi}

Efisiensi merupakan salah satu hal yang mesti menjadi target dalam setiap perusahaan Efisiensi adalah kemampuan untuk menyelesaikan suatu pekerjaan dengan benar atau dalam pandangan matematika didefinisikan sebagai perhitungan rasio output (keluaran) dan atau input (masuk) atau jumlah keluaran yang dihasilkan dari satu input yang digunakan. Suatu perusahaan dikatakan efisien apabila:

1. Menggunakan jumlah input yang lebih sedikit bila dibandingkan dengan jumlah unit input yang digunakan oleh perusahaan lain dengan menghasilkan output yang sama.

2. Menggunakan jumlah unit input yang sama dapat menghasilkan jumlah output yang lebih besar (Syafroedin dalam Muharram dan Purvitasari, 2000). Efisiensi juga berkaitan dengan biayabiaya yang ditimbulkan dalam melakukan aktivitas perusahaan. Efisiensi harus dapat dicapai perusahaan demi kelancaran kegiatan mereka. Sebuah perusahaan dengan efisiensi tinggi mencerminkan bahwa mereka dapat menyelesaikan setiap pekerjaan sesuai target yang telah ditetapkan.

Tujuan efisiensi adalah untuk mencapai keuntungan optimal. Dalam Islam istilah efisiensi tidak dikenal. Menekan biaya yang sebesar-besarnya untuk mendapatkan keuntungan yang paling maksimal dalam teori produsen akan berakibat pada perbuatan dzalim yang tidak bersenyawa dengan ruh Islam. Dalam Islam, perwujudan keuntungan yang optimal dihasilkan melalui usaha yang optimal (kerja keras) untuk menghasilkan sesuatu secara optimal 
Bakhitah, et al/Jurnal Ekonomi Syariah Teori dan Terapan Vol. 6 No. 6 Juni 2019: 1287-1303; EFISIENSI SEBAGAI STRATEGI UNTUK MENINGKATKAN KINERJA KEUANGAN (STUDI KASUS: BMT UGT SIDOGIRI CABANG LUMAJANG)

dengan tetap menjaga keseimbangan (ta'adul) dan etika syariah.

Keuntungan yang dihasilkan harus seimbang dengan kerja keras dan beban yang dikeluarkan. Rasulullah saw dalam Khan (2008) bersabda, Al-Kharaj bidDhaman (setiap keuntungan yang didapatkan harus sesuai dengan beban yang dikeluarkan). Keseimbangan juga berarti bahwa dalam mewujudkan value added, produsen mesti

memperhatikan aspek sosial, ekonomi, dan lingkungan. Untuk mewujudkan optimalisasi dan keseimbangan, Islam memberikan beberapa guidance, di antaranya:

a. Memanfaatkan seluruh potensi sumber daya alam Islam menghendaki umatnya untuk bekerja memakmurkan bumi dan memanfaatkan seluruh potensi sumber daya alam.

b. Spesialisasi kerja

Konsep spesialisasi kerja pernah diutarakan oleh Ibnu Khaldun dalam Muqaddimahnya. Menurutnya dengan jumlah penduduk yang semakin besar, maka akan terjadi pembagian dan spesialisasi tenaga kerja sehingga akan memperbesar surplus dan perdagangan internasional. Pembagian tenaga kerja internasional akan lebih tergantung pada perbedaan keahlian dan keterampilan penduduk dibandingkan dengan ketersediaan sumber daya alam. Dalam Islam, prinsip dasar tentang spesialisasi dapat ditelaah dalam hadits Nabi saw yang menjelaskan tentang konsep itqan dan ihsan.

c. Larangan terhadap Riba

Salah satu cara Islam mewujudkan efisiensi dengan cara minimalisasi biaya produksi adalah dengan pengharaman riba (bunga). Sebagai bagian dari elemen biaya tetap dalam produksi, penghapusan bunga akan membuat biaya produksi lebih rendah (efisien).

d. Larangan israf dan tabdzir dalam produksi

Perbedaan antara israf dan tabdzir disampaikan oleh Al-Mawardi dalam Kantakji (2003). Al-Mawardi menjelaskan bahwa israf adalah kesalahan menggunakan takaran yang tepat, sedangkan tabdzir adalah kebodohan dalam menggunakan alokasi yang tepat.

\section{Strategi}

Strategi berasal dari kata Yunani yaitu strategia (stratos: militer, ag:memimpin) yang artinya seni atau ilmu untuk menjadi seorang jendral. Strategi juga bisa dartikan sebagai suatu rencana untuk pembagian dan penggunaankekuatan militer dan material pada daerah tertentu untuk mencapai tujuan tertentu.Stretegi adalah sarana bersama dengan tujuan jangka panjang hendak dicapai (David, 2003: 18). Strategi adalah rencana yang disatukan, menyeluruh dan terpadu yangmengkaitkan keunggulan strategi bahwa tujuan utama perusahaan dapat 
Bakhitah, et al/Jurnal Ekonomi Syariah Teori dan Terapan Vol. 6 No. 6 Juni 2019: 1287-1303; EFISIENSI SEBAGAI STRATEGI UNTUK MENINGKATKAN KINERJA KEUANGAN (STUDI KASUS: BMT UGT SIDOGIRI CABANG LUMAJANG)

dicapai melalui pelaksanaan yang tepat oleh perusahaan (Glueck, 1998: 12). Strategi adalah rumusan perencanaan komprehensif tentang bagaimana perusahaan akan mencapai misi dan tujuannya. Strategi akan memaksimalkan keunggulan kompetitif dan meminimalkan keterbatasan bersaing (Hunger dan Wheelen, 2003:16).

\section{Kinerja Keuangan}

Kinerja keuangan adalah gambaran kondisi keuanganperusahaan pada suatu periode tertentu baik menyangkut aspek penghimpunan dana maupun penyaluran dana, yang biasanya diukur dengan indikator kecukupan modal, likuiditas, dan profitabilitas (Jumingan, 2006:239). Tujuan akhir yang ingin dicapai oleh koperasi adalah mensejahterakan anggotanya, sehingga diperlukan laba yang maksimal seperti yang ditargetkan. Namun dalam memperoleh keuntungan, haruslah sesuai dengan syariat Islam dan meninggalkan segala bentuk usaha yang bathil, seperti yang telah dijelaskan dalam firman Allah QS An-Nisa Ayat 29:

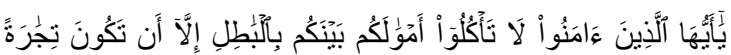

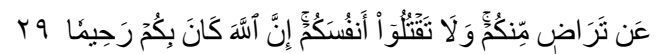
Artinya :"Hai orang-orang yang beriman, janganlah kamu saling memakan harta sesamamu dengan jalan yang batil, kecuali dengan jalan perniagaan yang berlaku dengan suka sama-suka di antara kamu. Dan janganlah kamu membunuh dirimu; sesungguhnya Allah adalah Maha Penyayang kepadamu."

\section{METODE PENELITIAN}

Pendekatan penelitian yang digunakan di dalam penelitian ini adalah penelitian kualitatif dengan strategi penelitian yang digunakan studi kasus. Pada penelitian ini memiliki satu objek yaitu BMT UGT Sidogiri Cabang Lumajang. Data diperoleh melalui interview terhadap beberapa informan tertentu, kemudian setelah data terkumpul dilakukan dengan triangulasi sumber data. Teknik analisis yang dgunakan adalah pembuatan eksplanasi.

\section{HASIL DAN PEMBAHASAN}

Apabila suatu perusahaan mempunyai tingkat efisiensi yang lebih tinggi dari kompetitor (low cost structure) maka perusahaan dapat menerapkan salah satu dari dua strategi berikut, yaitu: pertama, memaksimalkan profit dengan jalan menjaga tingkat harga dan ukuran perusahaan; dan kedua, memaksimalkan profit dengan jalan menurunkan harga dan memperluas ukuran perusahaan. Bila perusahaan menerapkan strategi terakhir, maka perusahaan yang efisien akan memperoleh pangsa pasar dan efisiensi perusahaan yang akan mendorong proses penetrasi pasar. Efisiensi menekankan pada efisiensi operasi yang dapat menurunkan biaya rata-rata karena peningkatan output. Menurut Ardi (2015) dalam penelitiannya yang berjudul "Efisiensi Baitul Mal Wa Tamwil (BMT) Anggota Induk Koperasi Syariah Dengan Metode Data Envelopment Analysis (DEA)" menyarankan untuk BMT yang 
Bakhitah, et al/Jurnal Ekonomi Syariah Teori dan Terapan Vol. 6 No. 6 Juni 2019: 1287-1303; EFISIENSI SEBAGAI STRATEGI UNTUK MENINGKATKAN KINERJA KEUANGAN (STUDI KASUS: BMT UGT SIDOGIRI CABANG LUMAJANG)

inefisien dituntut untuk dapat meningkatkan pembiayaan dan pendapatan operasional dengan memberikan lebih banyak pembiayaan kepada anggota sehingga pendapatannya dapat meningkat dengan syarat Non Performing Finance (NPF) nya dapat dituturunkan. Misalnya dengan menggencarkan sosialisasi mengenai pembiayaan, berwirausaha dan lain sebagainya, atau dengan mengurangi simpanan, menurunkan besarnya simpanan pokok dan simpanan wajib, juga mengurangi beban operasional seperti menekan gaji karyawan sesuai dengan kinerjanya dan dipergunakan untuk mengadakan pelatihan untuk dapat meningkatan kualitas karyawan agar dapat bekerja lebih efisien. Hal tersebut juga dilakukan BMT UGT Sidogiri terkait strategi efisiensi untuk meningkatkan kinerja keungan, yaitu di antaranya:

1. Meningkatkan Dana Pihak Ketiga (DPK) dan Penyaluran Pembiayaan

Secara umum BMT dipahami sebagai financial intermediary institution atau lembaga perantara keuangan dari dua pihak yaitu pihak yang kelebihan dana dan pihak yang kekurangan dana. Salah satu tolak ukur dalam rangka mengukur kinerja BMT khususnya yang berkenaan dengan pelaksanaan fungsi intermediasi adalah dengan menggunakan Finance to Deposit Ratio (FDR), yaitu perbandingan atau ratio antara Dana Pihak Ketiga (DPK) yang berhasil dihimpun oleh BMT (pelaksanaan fungsi intermediasi penghimpunan dana) terhadap penyaluran dana dalam bentuk Pembiayaan (pelaksanaan fungsi penyaluran dana). Dilihat dari komponen pembentuknya FDR merupakan suatu ukuran ideal yang dapat digunakan untuk mengukur kinerja BMT sebagai lembaga intermediasi (Abdullah, 2003 : 16). Tujuan perhitungan FDR adalah untuk mengetahui serta menilai sampai berapa besar jauh suatu BMT memiliki kondisi sehat dalam menjalankan operasi atau kegiatan usahanya. Bapak Sugeng Riadi mengatakan sebagai salah satu upaya dalam efisiensi biaya untuk meningkatkan kinerja keuangan, BMT UGT Sidogiri Cabang Lumajang berupaya meningkatkan DPK dan penyaluran pembiayaan.

"jadi yang pertama untuk meningkatkan kinerja keuangan harus meningkatkan simpanannya dulu setelah simpanan ditingkatkan kemudian ditingkatkan juga penyaluran pembiayaan karena kita bergerak di simpan dan pinjam bagaimana simpanan FDRnya $85 \%$ itu bisa disalurkan sebagia pembiayaan, jadi kita lihat DPK kita berapa persen disalurkan apabila masih dibawah $85 \%$ maka ya kita tinjau agar disalurkan ketika penyalurannya sudah diatas $85 \%$ ini harus bagaimana? Maka simpanannya yang harus diperbanyak maka kita bisa sampaikan kepada bagian KBSP ( kepala bagian SImpanan dan pinjam) eh ini FDR kita sudah sekian ini simpanannya harus ditingkatkan di angka sekian. jadi 85\%-100\% dana simpanan atau DPK itu disalurkan sebagai pembiayaan, dari pembiayaan itu nanti kan dari 
Bakhitah, et al/Jurnal Ekonomi Syariah Teori dan Terapan Vol. 6 No. 6 Juni 2019: 1287-1303; EFISIENSI

SEBAGAI STRATEGI UNTUK MENINGKATKAN KINERJA KEUANGAN (STUDI KASUS: BMT UGT SIDOGIRI CABANG LUMAJANG)

angsuran yang masuk kita akan catat hasil setiap bulan yaitu dengan pembiayaan yang meningkat sehingga otomatis pendapatan juga meningkat..."

Tak hanya itu, bapak muhyiddin juga menuturkan pernyataan yang serupa.

"untuk meningkatkan kinerja keuangan tiap hari kita ada peningkatan prospek, juga ketika kita terus berinteraksi baik itu dengan applikasi yang ada harus ada inovasi dari kami... serta dengan kita memperbanyak pembiayaan baru..."

Pernyataan tersebut juga diperkuat oleh pernyataan bapak shodik

"untuk meningkatkan pendapatan ya harus DPK yang banyak dan penyaluran yang banyak dan terarah..."

"normalnya antara 85\%-110\% untuk FDR-nya"

Berdasarkan ketiga pernyataan tersebut saling menguatkan bahwa strategi untuk meningkatkan kinerja keungan yaitu dengan berupaya dalam meningkatkan dana Pihak ketiga (DPK) yaitu simpanan berupa tabungan dan deposito berjangka serta menempatkan dana yang ada pada prospek yang tepat dan terarah dan dengan mempertahankan rasio FDR sebesar 85$110 \%$, prinsip dasar tentang hal tersebut dapat ditelaah dalam hadits Nabi saw yang menjelaskan tentang konsep itqan dan ihsan. Mengenai itqan, Rasulullah saw bersabda:

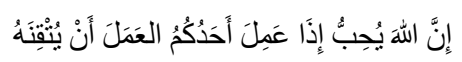

Artinya, "Sesungguhnya Allah sangat mecintai orang yang jika melakukan sesuatu pekerjaan, dilakukan secara Itqan (tepat, terarah, jelas dan tuntas)." (HR. Thabrani)

Sehingga dapat disimpulkan bahwa BMT UGT Sidogiri menerapkan ajaran islam untuk senantiasa melakukan kegiatan operasionalnya dengan konsep itqan dan ihsan.

2. Meningkatkan fee based income

Menurut Kasmir dalam bukunya berjudul "Bank dan Lembaga Keuangan Lainnya" menyebutkan bahwa yang dimaksud dengan fee based income adalah keuntungan yang didapat dari hasil transaski atau jasa bank lainnya spread based. Fee Based Income adalah bagian dari kegiatan lain perbankan selain menghimpun dan menyalurkan dana. Tujuannya adalah untuk mendukung dan memperlancar kedua kegiatan utama tersebut. Menurut Kasmir keuntungan yang didapat bank dari aktivitas fee based income adalah perolehan yang didapat mengandung kepastian, memperlancar transaksi simpanan yang ada, ragam penghasilan lebih banyak. Hal ini juga diterapkan di BMT UGT Sidogiri Lumajang seperti yang disampaikan Bapak sugeng dalam meningkatkan kinerja keuangan bisa dalam bentuk peningkatan layanan jasa yang ditawarkan oleh BMT.

"...Kemudian strategi yang kedua untuk meningkatkan kita juga ada jasa, jasa transfer ke seluruh perbankan seperti biaya admin cuma kita masih menggunakan sistem net banking perbankan bukan menggunakan sistem kita sendiri. Jadi biaya-biaya itu kalau dari bank 5000 kita dari BMT 7000 
sehingga selisih 2000 tersebut pendapatan bagi kita. Selain jasa transfer kita juga ada orang beli pulsa, jasa pembayaran token listrik dimana jasa-jasa tersebut bisa dilakukan melalui mobile UGT untuk nasabah..."

Sama halnya, itu juga diutarakan oleh bapak Muhyiddin

"ya itu tadi dengan kita memperbanyak pembiayaan baru begitu juga kita memaksimalkan jasa, jasa itu baik itu transfer, mobile UGT, terus pelayanan-pelayanan seperti pembayar listrik, pembayaran Telkom itu jasa kita."

Kedua pernyataan tersebut juga diperkuat oleh pernyatann oleh bapak Shodik

“...Kemudian jasa diantaranya bisa transfer antar bank juga pembayaran PDAM, pengurusan haji terus pengurusan tentang perpanjangan pajak kendaraan."

Ketiga pernyataan di atas dapat disimpulkan bahwa BMT UGT Sidogiri juga menyediakan jasa atau layanan berupa pembayaran listrik, pembelian pulsa, perpanjangan pajak, transfer antar Bank, dll hal itu merupakan upaya lain dalam meningkatkan pendapatan BMT.

3. Melakukan inovasi pada teknologiteknologi yang digunakan

Teknologi menjadi bagian penting yang mendukung keberhasilan strategi suatu perusahaan ataupun organisasi. Karena itu, pihak manajemen tidak segansegan menginvestasikan sejumlah dana untuk kepentingan teknologi. Teknologi menjadi penentu perusahaan saat berhadapan dengan para pesaingnya. BMT memiliki fitur mobile UGT. Mobile UGT ini memiliki fitur yaitu bisa untuk mengetahui saldo tabungan, transaksi, pembelian pulsa dan pembayaran listrik. Dari adanya fitur di atas semakin memudahkan nasabah untuk melakukan transaksi pembayaran. Dengan di terbitkan mobile UGT hal itu merupakan upaya BMT UGT Sidogiri dalam melakukan inovasi pada teknologi yang digunakan hal itu dijelaskan oleh Pak sugeng sebagai berikut:

"...jadi di BMT ada anak perusahaan namanya USID bagian pembuatan sistem onlinenya sistem SIS BMTnya applikasi BMT nya itu semua USID lalu ada USAD itu bagian koneksinya"

"...transaksi-transaksi pembelian pulsa, token listrik, pembayaran PDAM, internet dapat dilakukan melalui mobile UGT tersebut dan dari situ kita mendapatkan pendapatan. Jadi memang dari sisi teknologi kita tidak boleh ketinggalan karena semakin lama tenaga manusia akan semakin sedikit dibutuhkan karena kecanggihan sistem teknologi..."

Hal ini juga dilengkapi dengan pernyataan bapak Shodik bahwa teknologi juga merupakan upaya BMT dalam meningkatkan efisiensi dalam bekerja.

"ya disini ada SIS BMT nya sendiri terkait proses pengentryan atau checklist disitu, BMT selalu memikirkan inovasi-inovasi sekiranya bekerja ini tambah mudah, tambah terarah, tambah baik, jadi kita mikirnya disitu juga sehingga kas opname harian kalau pake manual terus nanti akan kewalahan dan juga kita cari inovasi-inovasi dengan selalu berkoordinasi dengan kepala cabang juga nambah-nambah ilmu dari yang lain yang sudah mumpuni 
Bakhitah, et al/Jurnal Ekonomi Syariah Teori dan Terapan Vol. 6 No. 6 Juni 2019: 1287-1303; EFISIENSI SEBAGAI STRATEGI UNTUK MENINGKATKAN KINERJA KEUANGAN (STUDI KASUS: BMT UGT SIDOGIRI CABANG LUMAJANG)

karena sistem yang memakai Linux."

Menurut pak shodik dengan adanya teknologi yang semakin canggih hal itu dapat memudahkan karyawan dalam bekerja dengan baik sehingga hal ini merupakan salah satu tindakan yang efisiensi. Strategi yang mendorong pemanfaatan teknologi digital dan terus berinovasi, lewat penyempurnaan proses bisnis dengan operasional berbasis teknologi informasi (TI). Hal ini merujuk pada QS. Ar-Ra'd : 11 sebagai berikut:

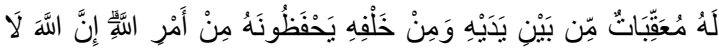

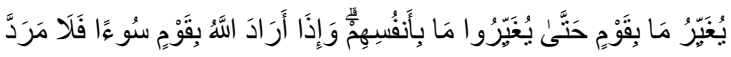

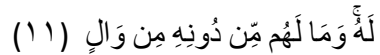

lahụ mu'aqqibātum mim baini yadaihi wa min khalfihī yaḥfaẓunahụ min amrillāh, innallāha lā yugayyiru mā biqaumin ḥattā yugayyirụ mā bi anfusihim, wa iżā arādallāhu biqaumin sū an fa lā maradda lah, wa mā lahum min dụnihī miw wāl

Artinya: Bagi manusia ada malaikatmalaikat yang selalu mengikutinya bergiliran, di muka dan di belakangnya, mereka menjaganya atas perintah Allah. Sesungguhnya Allah tidak merubah keadaan sesuatu kaum sehingga mereka merubah keadaan yang ada pada diri mereka sendiri. Dan apabila Allah menghendaki keburukan terhadap sesuatu kaum, maka tak ada yang dapat menolaknya; dan sekali-kali tak ada pelindung bagi mereka selain Dia.

Ayat tersebut mengandung motivasi untuk inovatif dengan merubah manajemen dan sistem agar tidak tertinggal ketika yang lain maju. Bahkan dengan selalu berinovasi maka kita akan menjadi yang terdepan. Upaya tersebut juga mengarah pada sabda Rasulullah SAW:

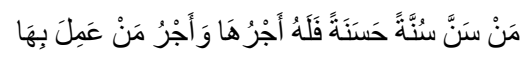

Artinya:"Barang siapa melakukan hal baru yang baik maka ia mendapat pahalanya dan mendapat pula pahala orang lain yang mengerjakan hal baru yang baik itu." [HR. Muslim]

Hadist tersebut mengandung motivasi untuk kreatif. Kata "sanna" dalam bahasa Arab, berarti melakukan hal baru, ketika hal yang baru itu bersifat baik maka kita menyebutnya kreatifitas. Hadits ini adalah salah satu kebanggakan ummat Islam karena mengandung konsep modern, dan itu berati sebenarnya pemikiran ummat Islam sudah modern sejak empat belas abad yang silam. Sehingga apa yang dilakukan oleh BMT UGT Sidogiri Cabang Lumjang sesuai dengan tuntunan ajaran islam agara selalu berinovasi dan berfikir kreatif.

4. Mentargetkan setiap karyawan

Target atau tujuan merupakan penggerak dan acuan dalam semua aktivitas. Tanpa tujuan, gerak dan semua pekerjaan tidak akan terarah, hanya menjadi rutinitas menjemukan dan tidak menghasilkan apa-apa kecuali membuang waktu saja. Potensi sumberdaya manusia yang ada di dalamnya akan mencapai kemajuan maksimal atau mendapatkan pencapaian tertinggi yang semestinya 
Bakhitah, et al/Jurnal Ekonomi Syariah Teori dan Terapan Vol. 6 No. 6 Juni 2019: 1287-1303; EFISIENSI SEBAGAI STRATEGI UNTUK MENINGKATKAN KINERJA KEUANGAN (STUDI KASUS: BMT UGT SIDOGIRI CABANG LUMAJANG)

bisa diraih dengan mengoptimalkan semua daya dan upaya, tenaga, fikiran serta totalitas. Keuntungan yang didapat pun akan semakin meningkat. Konsep manajemen Qur'ani menjelaskan bahwa setiap manusia (bukan hanya organisasi) hendaknya memperhatikan apa yang telah diperbuat pada masa yang telah lalu untuk merencanakan hari esok. Dalam Al Qur'an Allah berfirman:

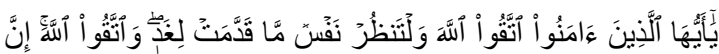

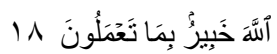
yā ayyuhallażīna āmanuttaqullāha waltanz̧ur nafsum mā qaddamat ligad, wattaqullāh, innallāha khabìrum bimā ta'malụn

Artinya: Hai orang-orang yang beriman, bertakwalah kepada Allah dan hendaklah setiap diri memperhatikan apa yang telah diperbuatnya untuk hari esok (akhirat); dan bertakwalah kepada Allah, sesungguhnya Allah Maha Mengetahui apa yang kamu kerjakan.

Berdasarkan ayat tersebut adalah perintah kepada orang-orang yang beriman dimulai dengan bertakwa kepada Allah untuk selanjutnya mempersiapkan bekal untuk masa depannya baik begitupula untuk kinerja keungan diperlukannya mempersiapkan upaya untuk mendapatkan hasil yang baik. Segala yang dilakukan adalah kebaikan dan membawa manfaat baik untuk diri sendiri maupun orang lain, dan juga penuh kewaspadaan dan kehatihatian sehingga segalanya terencana dengan baik dan jauh dari kecerobohan.
Dalam pelaksanaan dilaksanakan dengan sungguh-sungguh, sesuai visi, misi dan target dengan pengendalian, monitoring dan pengawasan yang profesional. Maka dari itu BMT UGT Sidogiri untuk meningkatakan kinerja keuangan salah satunya dengan cara mentargetkan setiap karyawan seperti yang disampaikan oleh pak Sugeng sebagai berikut:

“...dari AO SP dia targetnya 8 juta per hari dari tabungan baru, nominal tabungan per hari dapat berapa, kemudian 1 hari berapa transaksi, kalau disini minimal 100 transaksi per hari untuk 1 AO..."

Pernyataan tersebut juga diperkuat dengan yang disampaikan oleh pak muhyiddin

"...kita liat dengan cara
mengkontrol capem-capem tiap
pekan seumpama ya AO SP ini
bagian DPK ini target tiap hari per
pecan juga ada tapi itu yang
menghandle kepala cabang, saya
menghandlenya prospeknya 5
orang untuk satu AO SP nah
realitanya dari target yang didapat
ada yang tidak sampek target
hanya 3 ada juga yang lebih seperti
itu, kita ketika oh ini bisa ditargetkan
lebih otomatis kita akan tambah,
kita nambahnya melihat 2 atau 3
tiap pekannya bisa juga kita
kurangin..."

Kedua pernyataan tersebut saling menguatkan dan hal itu menjelaskan bahwa memberi target kepada karyawan merupakan salah satu cara untuk meningkatkan kinerja keungan BMT.

5. Meningkatkan kinerja Sumber Daya Manusia

Kinerja suatu organisai atau lembaga tergantung pada kompetensi 
sumber daya manusia di dalamnya. Sumber daya manusia adalah aset bagi organisasi. Untuk itu, lembaga yang cerdas dan berkeinginan meningkatkan kinerjanya, harus berupaya mengembangkan sumber daya manusianya secara berkelanjutan. Sumber daya manusia yang memiliki pengetahuan dan keterampilan baik itu bisa meningkatkan kualitas kinerjanya. Menurut bapak sugeng meningkatkan efisiensi pada sumber daya manusia dapat dilakukan dengan cara merubah sistem penggajian karyawan seperti yang dijelasakan berikut:

"ya ini juga termasuk gaji karyawan beberapa tahun yang lalu dia dapet berapapun gajinya ya sekian seumpama 4 juta ya jadi antara karyawan yang terbaik dengan karyawan yang tidak produktif itu sama gajinya 4 juta tadi. Sedangkan bagaimana ini bisa efisien maka dirubahlah sistem penggajian di BMT ini seperti tadi sistem bonus jadi karyawan yang rajin dapat banyak kalau yang kurang rajin ya dapat sedikit itu juga termasuk langkah efisiensi."

Bonus yang diberikan sangat bergantung pada baik buruknya produktivitas karyawan. seperti yang dikatakan bapak sugeng terkait pengukuran bonus yang diberikan kepada para karyawan sebagai berikut:
"produktivitas, semakin dia produktif semakin banyak bonus yang di dapat, contoh dari AO SP dia targetnya 8 juta per hari dari tabungan baru, nominal tabungan per hari dapat berapa, kemudian 1 hari berapa transaksi, kalau disini minimal 100 transaksi per hari untuk $1 \mathrm{AO}$, Alhamdulillah disini lebih dari

100 transaksi per harinya. Kemudian dilihat juga dari angsuran pokok yang masuk itu juga jadi pertimbangan kalau missal nilainya 5 secara keseluruhan maka bonus akan diperoleh $100 \%$ kalau hanya mencapai $80 \%$ maka bonusnya $80 \%$. Jadi bonus untuk setiap karyawan juga berbeda-beda tergantung level jabatan jadi ada Al A2 B1 B2."

Kemudian menurut pak muhyiddin juga mengatakan bahwa dalam pemberian bonus kepada karyawan dapat meningkatkan efisiensi sumber daya manusia dalam memicu semangat para karyawan.

"jadi kita ada bonusan untuk menyemangati temen-temen. Jadi oh ini kalau bisa mencapai target sekian nanti kamu dapat sekian tapi kalau kamu gak mencapai sekian nanti kamu dapet hasilnya sekian."

Berdasarkan pernyataan pak sugeng dan pak muhyiddin dapat disimpulkan bahwa bonus karyawan yang mendapat nilai keseluruan nilai 5 maka akan mendapat tunjangan penuh 100\%, jika kurang dari target maka akan mendapat bonus sesuai dengan prosentase target tabungan yang telah ditentukan. Dengan bonus tersebut diharapkan kinerja karyawan akan semakin baik. Selain pemberian bonus, cara meningkatkan efisiensi yaitu karyawan diberi pelatihan-pelatihan sesuai dengan jabatan masing-masing karyawan. Dengan pelatihan karyawan tersebut di maksudkan untuk meningkatkan kinerja para karyawan. Hal 
ini dijelaskan oleh Bapak Sugeng sebagai

berikut:

"...memanfaatkan sumberdaya yang ada, kan seperti itu memang harus efisien. tenaga-tenaga yang ada ini juga harus dibekali dengan tambahan pengetahuan, skill, bagaimana untuk meningkatkan produktivitas di BMT. Seperti sekarang ini kepala cabang pembantu di seluruh Indonesia ini selama 3 hari mereka diberikan tambahan skill dan pengetahuan yaitu dengan ada pelatihan untuk kepala kantor, pelatihan untuk kasir, pelatihan untuk AO SP dan lain sebagainya..."

Pernyataan ini juga diperkuat dengan pernyataan bapak Muhyiddin bahwa adanya pelatihan yang diberikan kepada karyawan.

"yang pertama saat program magang diawal kerja. Kalau sudah jadi karywan ada juga pelatihan yang akan saya ikuti jumat depan namanya pelatihan UMMI memang pelatihannya diadakan 1 tahun sekali dari pusat. Pelatihan ini nanti kita mendampingi para debiturdebitur yang mempunyai usaha. Lalu karyawan yang mendampingi ini ada 4 dari kabupaten lumajang 1 saya perwakilan dari cabang, 1 dari capem jatiroto, 1 capem ranuyoso dan lcapem sukodono. Pemilihannya diacak dan melihat dari kinerjanya dia sanggup untuk mendampingi. Lalu untuk karyawan yang masih kurang baik dalam hal komunikasi di nasabah itu nanti akan didampingi secara personal biasanya itu permintaan dari kepala capemnya sendiri."

\section{Berdasarkan}

pernyataan-

pernyataan tersebut saling menguatkan dan melengkapi bahwa untuk meningkatkan kinerja para karyawan dapat berupa pemberian bonus dan pelatihan untuk karyawan. Hal ini merupakan salah satu cara untuk meningkatkan efisiensi pada BMT UGT Sidogiri. Kinerja karyawan yang bagus dapat memberikan manfaat bukan hanya individunya tetapi bisa memberikan manfaat bagi organisasi dan manajernya. Sebaliknya bagi karyawan yang kurang baik dalam pencapaian kinerjannya maka disini kewajiban pihak lembaga untuk memberikan bimbingan dan pendampingan yang belum sesuai dengan target. Dengan memberikan pendampingan diharapkan bisa memperbaiki kinerja karyawan agar bisa tercapainya tujuan organisasi dimasa depan dapat tercapai dengan baik. Strategi yang dilakUkan BMT UGT Sidogiri Cabang Lumajang dalam meningkatkan kinerja sumber daya manusia dengan menetapkan tingkat upah atau insentif para karyawan yang menerima pembayaran lebih untuk keluaran yang lebih besar, serta pemberian pelatihan pada karyawan dilakukan guna memotivasi karyawan untuk lebih produktif dalam bekerja. Upaya tersebut mengarah pada QS At-taubah ayat 105 sebagai berikut:

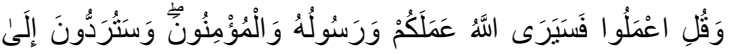

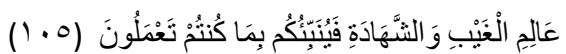

wa quli'malụ fa sayarallāhu 'amalakum wa rasulluhụ wal-mu'minụn, wa saturadduna ilā 'ālimil-gaibi wasy-syahādati fa yunabbi' 'ukum bimā kuntum ta'malụn Artinya :Dan Katakanlah: "Bekerjalah kamu, maka Allah dan Rasul-Nya serta orang-orang mukmin akan melihat 
Bakhitah, et al/Jurnal Ekonomi Syariah Teori dan Terapan Vol. 6 No. 6 Juni 2019: 1287-1303; EFISIENSI SEBAGAI STRATEGI UNTUK MENINGKATKAN KINERJA KEUANGAN (STUDI KASUS: BMT UGT SIDOGIRI CABANG LUMAJANG)

pekerjaanmu itu, dan kamu akan dikembalikan kepada (Allah) Yang Mengetahui akan yang ghaib dan yang nyata, lalu diberitakan-Nya kepada kamu apa yang telah kamu kerjakan. IQS At Taubah: 105)

Maksud dari ayat ini adalah Allah memerintahkan kepada mereka yang bertobat, untuk bekerja dengan berbagai pekerjaan yang mendatangkan manfaat. Di samping itu, Allah juga memerintahkan kepada Rasul-Nya agar menyampaikan kepada umatnya, bahwa Allah akan melihat pekerjaanmu, dan memberi penghargaan atas pekerjaanmu, begitu juga Rasul-Nya dan orang-orang mukmin juga akan menyaksikan dan menilai pekerjaanmu, dan kamu akan dikembalikan, yakni meninggal dunia dan pada hari kebangkitan semua makhluk akan kembali kepada Allah Yang Mengetahui yang gaib dan yang nyata, lalu diberitakanNya kepada kamu apa yang telah kamu kerjakan di dunia, baik yang kamu tampakkan atau yang kamu sembunyikan.(Tafsir Lengkap Departemen Agama)

Berdasarkan ayat tersebut untuk bisa produktif, individu atau organisasi harus aktif dalam tugasnya/pekerjaannya. Sejalan dengan firman-Nya : "Bekerjalah kamu, maka Allah dan Rasul-Nya serta orang-orang mukmin akan melihat pekerjaanmu itu." dan pekerjaan tersebut akan diberikan imbalan yang setimpal dengan apa yang dikerjakan. Jadi dapat disimpulkan bahwa upaya yang dilakukan
BMT UGT Sidogiri Cabang Lumajang dengan konsep produktivitas sejalan dengan nilai-nilai pada agama Islam yang jika dilakukan akan dapat membuat perubahan kearah yang lebih baik.

\section{SIMPULAN}

BMT UGT Sidogiri Cabang Lumajang dalam menjalankan kegiatannya mentanamkan kepada para anggota koperasi dan penerima amanat perlu memiliki karakter STAF, yaitu Shiddiq (jujur), Tabligh (Transparan), Amanah (dapat dipercaya) dan Fathanah (Profesional). Hal tersebut yang mendasari BMT UGT Sidogiri dalam menilai efisiensi berdasarkan pada konsep efisiensi yang mereka miliki dan yakini dimana efisiensi merupakan keberhasilan sebuah kegiatan yang dinilai berdasarkan besarnya biaya/ sumber daya yang digunakan untuk mencapai hasil yang diinginkan. Kinerja Keuangan yang baik sebagai modal dasar untuk meraih visi, misi dan tujuan BMT salah satunya untuk meningkatkan kesejahteraan umat dan anggota. Kinerja yang baik tersebut tentu tidak lepas dari strategi yang telah direncanakan secara bersama-sama oleh seluruh tim pengurus dan pengelola BMT UGT Sidogiri Cabang Lumajang. Strategi adalah garis besar tindakan untuk mencapai sasaran hasil yang ingin dicapai. Strategi efisiensi yang dapat dilakukan untuk meningkatkan kinerja kevangan BMT UGT Sidogiri Cabang Lumajang yaitu melakukan pengendalian biaya dengan cara penentuan yang didasari dari melihat 
Bakhitah, et al/Jurnal Ekonomi Syariah Teori dan Terapan Vol. 6 No. 6 Juni 2019: 1287-1303; EFISIENSI SEBAGAI STRATEGI UNTUK MENINGKATKAN KINERJA KEUANGAN (STUDI KASUS: BMT UGT SIDOGIRI CABANG LUMAJANG)

pengeluaran periode sebelumnya serta adanya kebijakan batas limit yang ditentukan oleh kantor pusat dengan cabang untuk persetujuan biaya yang akan dikeluarkan, Meningkatkan Dana Pihak Ketiga (DPK) berupa tabungan dan deposito berjangka, Menyalurkan pembiayaan secara jelas dan terarah dengan melakukan survey terlebih dahulu kepada calon nasabah pembiayaan, Meningkatkan layanan dan fitur produk fee based income, Melakukan inovasi pada teknologi-teknologi yang digunakan seperti adanya U-mobile untuk Account Officer (AO) dan mobile UGT untuk para anggota koperasi, Mentargetkan setiap karyawan agar lebih produktif dan efisien, Memberikan pelatihan menyangkut skill yang diperlukan dan public relationship kepada setiap karyawan dan yang terakhir Sistem penilaian kinerja, penghargaan dan promosi karyawan didasarkan atas kontribusi mereka dalam usaha peningkatan kualitas, produktivitas secara berkelanjutan

\section{DAFTAR PUSTAKA}

Akbar, Rifki Ali. 2010. Analisis Efisiensi Baitul Mal Wa Tamwil dengan Menggunakan Data Envelompent Analysis (DEA). Skripsi Universitas Diponegoro Semarang

Ali, M. Mahbubi dan Ascarya.2010. Analisis Efisiensi Baitul Maal Wat Tamwil dengan Pendekatan Two Stage Data Envelopment Analysis (Studi Kasus Kantor Cabang BMT MMU dan BMT UGT Sidogiri).TAZKIA
Islamic Finance \& Business Review Vol. 5 No. 2

Ascarya dan Diana. 2006. Analisis Efisiensi Perbankan Syariah di Indonesia dengan Data Envelopment Analysis, TAKZIA Islamic Finance and Business Review, Vol. 1, No. 2 Desember 2006

Ascarya dan Diana Yumanita. 2008. Comparing The Efficiency of Islamic Banks in Malaysia and Indonesia. Buletin Ekonomi Moneter dan Perbankan

Aziz, Abdul. 2008. Ekonomi Islam Analisis Mikro dan Makro. Yogyakarta: Graha llmu.

Bank Indonesia.(Online). (https://www.bi.go.id/id diakses pada tanggal 5 Mei 2019)

BMT UGT Sidogiri. (Online). (https://www.bmtugtsidogiri.co.id/ berita-.html diakses pada tanggal 10 September 2018)

Buchori,Nur S. 2012. Koperasi Syari'ah Teori dan Praktik. Banten: Pustaka Aufa Media

Darsono, dkk. 2017. Memberdayakan Kevangan Mikro Syariah Indonesia Peluang Dan Tantangan Ke Depan. Jakarta: TAZKIA PUBLISHING

David, Fred R. 2006. Manajmen Strategis: Konsep, Edisi 10 Buku 1. Jakarta: Penerbit Salemba Empat.

David, R. Fred. 2004. Konsep Manajemen Strategis Edisi VII. Jakarta: PT. Indeks. 
Bakhitah, et al/Jurnal Ekonomi Syariah Teori dan Terapan Vol. 6 No. 6 Juni 2019: 1287-1303; EFISIENSI

SEBAGAI STRATEGI UNTUK MENINGKATKAN KINERJA KEUANGAN (STUDI KASUS: BMT UGT SIDOGIRI CABANG LUMAJANG)

David, R. Fred. 2011 . Manajemen Strategis: Konsep. Jakarta: Salemba Empat.

Departemen Agama RI. Al-Quran \& Tafsirnya. Edisi yang disempurnakan. Jilid V. Jakarta: 2008.

Evan, Ardhi.201. Efisiensi Baitul Mal wa tamwil (bmt) anggota Induk Koperasi syariah Dengan Metode data Envelopment Analysis (DEA).Skripsi

Ginting, Isma IImi Hayati dan Ilyda Sudardjat.Analisis Strategi Pengembangan Bmt (Baitul Maal Wat Tamwil) Di Kota Medan. Jurnal Ekonomi dan Keuangan Vol.2 No.11

Gobel, Meryanti.2013.Analisis Efisiensi Biaya Operasional Melalvi Pengelolaan Tunjangan Makan Dan Jaminan Pemeliharaan Kesehatan Pada Perusahaan Jasa Outsourcing. Jurnal EMBA Vol.1 No.4, Hal. 18681878

Huda, Nurul dan Heykal Mohammad.2015. Lembaga Kevangan Islam Tinjauan Teoritis Dan Praktis. Jakarta: Kencana.

Hunger, J. David dan Thomas L. Wheelen. 2003. Manajemen Stratregis Edisi II. Jakarta: Gramedia Pustaka Utama. Jauch, R.L. \& Glueck, F.W.2004. Strategic Managementand Business Policy. New York: McGraw-Hill.

Kasmir.2008. Bank dan Lembaga Kevangan Lainnya.Jakarta: PT Raja Grafindo Persada
Kasmir.2012.Manajemen

Perbankan.

Jakarta: PT Grafindo Persada.

Kementerian Agama Republik Indonesia. (Online).

(https://jatim.kemenag.go.id

diakses pada 25 Maret 2019).

Moleong, Lexy J. 2001. Metodologi Penelitian Kualitatif. Bandung: Remaja Rosdakarya.

Obsessionnews. (Online). (www.obsessionnews.com diakses pada tanggal 10 Oktober 2018)

Peraturan Menteri Negara Koperasi Dan Usaha Kecil Dan Menengah Republik Indonesia Nomor : 35.3/Per/M.KUKM/X/2007

Praya, Lintang Gigih Abi.2017.Analisis Kinerja Keuangan Koperasi Simpan Pinjam Dan Pembiayaan Syariah Bmt Dana Insani Wonosari Tahun 2013-2015.Jurnal Pendidikan dan Ekonomi, Volume 6, Nomor 6, Tahun 2017

Rahmawati, Rafika.2015. Strategi Peningkatan Efisiensi Biaya Pada Bank Umum Syariah Berbasis Stochastic Frontier Approach Dan Data Envelopment Analysis. Buletin Ekonomi Moneter dan Perbankan, Volume 17, Nomor 4. Bogor : Pascasarjana Institut Pertanian Bogor

Ridwan, Muhammad. 2005. Manajemen Baitul Maal Wat Tamwil (BMT). Yogyakarta: UII Press.

Republik Indonesia. (2012). UndangUndang Republik Indonesia Nomor: 

CABANG LUMAJANG)

17 Tahun 2012 Tentang

Perkoperasian. Jakarta: Sekretariat Negara Republik Indonesia.

Sudarsono, Heri.2007. Bank dan Lembaga

Keungan Syariah. Yogyakarta:

Ekonisia

Soemitra, Andri. 2009. Bank dan Lembaga

Kevangan Syariah. Jakarta: Kencana.

Shihab, M. Quraish. 2002. Tafsir Al-Mishbah: Pesan, Kesan dan Keserasian AlQur'an. Vol. 7. Jakarta: Lentera Hati.

Ummah, Rohmatul.2010. Pengaruh Efisiensi Operasional Dengan Kinerja Kinerja kevangan Pada Sector Perbankan Syariah (Studi Kasus Bank Syariah Mandiri, Tbk).Skripsis UIN Syarif Hidayatullah Jakarta

Wawancara

Yin, R. K.1996. Studi kasus: Desain dan Metode. Jakarta: PT. Raja Grafindo.

.2015. Studi kasus: Desain dan Metode. Jakarta: PT. Raja Grafindo.

Yuliani. 2007. "Hubungan Efisiensi Operasional dengan Kinerja Profitabilitas Pada Sektor Perbankan yang Go Publik di Bursa Efek Jakarta". Jurnal Manajemen Bisnis Sriwijaya.Vol. 5. No. 10 : 15-43. 